\title{
Antileishmanial and trypanocidal activity of Brazilian Cerrado plants
}

\section{Mariana Laundry de Mesquita, Julie Desrivot*, Christian Bories*, Alain Fournet**, José Elias de Paula***, Philippe Grellier****, Laila Salmen Espindola/ ${ }^{+}$}

\begin{abstract}
Laboratório de Farmacognosia, Faculdade de Ciências da Saúde, Campus Universitário Darcy Ribeiro, Universidade de Brasília, 70910-900 Brasília, DF, Brasil *Laboratoire de Pharmacognosie et Groupe Chimiothérapie Antiparasitaire UMR 8076 CNRS,

**IRD US 084 Laboratoire de Pharmacognosie, Faculté de Pharmacie, Université Paris-Sud, Châtenay-Malabry, France

***Laboratório de Anatomia Vegetal, Departamento de Botânica, Instituto de Biologia, Universidade de Brasília, Brasília, Brasil

****USM 0504 Biologie Fonctionnelle des Protozoaires, Département Régulations, Développement, Diversité Moléculaire,

Muséum National d'Histoire Naturelle, Paris, France
\end{abstract}

The side effects and the emerging resistance to the available drugs against leishmaniasis and trypanosomiasis led to the urgent need for new therapeutic agents against these diseases. Thirty one extracts of thirteen medicinal plants from the Brazilian Cerrado were therefore evaluated in vitro for their antiprotozoal activity against promastigotes of Leishmania donovani, and amastigotes of Trypanosoma cruzi. Among the selected plants, Casearia sylvestris var. lingua was the most active against both $\mathrm{L}$. donovani and $\mathrm{T}$. cruzi. Fifteen extracts were active against promastigotes of $\mathrm{L}$. donovani with concentrations inhibiting $50 \%$ of parasite growth $\left(I_{50}\right)$ between 0.1-10 $\mu \mathrm{g} / \mathrm{ml}$, particularly those of Annona crassiflora (Annonaceae), Himatanthus obovatus (Apocynaceae), Guarea kunthiana (Meliaceae), Cupania vernalis (Sapindaceae), and Serjania lethalis (Sapindaceae). With regard to amastigotes of $\mathrm{T}$. cruzi, extracts of A. crassiflora, Duguetia furfuracea (Annonaceae), and C. sylvestris var. lingua were active with IC $C_{50}$ values between $0.3-10 \mu \mathrm{g} / \mathrm{ml}$. Bioassay fractionations of the more active extracts are under progress to identify the active antiparasite compounds.

Key words: Brazilian Cerrado plants - leishmaniasis - Chagas disease - Leishmania donovani - Trypanosoma cruzi - Brazil

Leishmaniasis and trypanosomiasis are a group of globally widespread parasitic diseases responsible for considerable mortality and morbidity, affecting millions of people every year (WHO 2002). Chagas disease (American trypanosomiasis) is caused by the flagellated protozoan Trypanosoma cruzi and is transmitted to humans by triatomine (hematophagous) insects known popularly as "kissing bug", "vinchuna", and "barbeiro". The two drugs used in clinical practice, nifurtimox and benznidazole, do not eliminate the parasites, and resistance was reported (Urbina 1999, Urbina \& Docampo 2003). Leishmaniasis is transmitted by the bite of an infected female sand fly of the genera Phlebotomus and Lutzomya. Leishmania donovani is the causative agent of visceral leishmaniasis, which is fatal in the absence of treatment (Paris et al. 2004). In the treatment of leishmaniasis, drugs that can be used are pentavalent antimonials (meglumine antimoniate or sodium stibogluconate), amphotericin B, and pentamidine salts, which may cause serious side-effects and unresponsive therapies (Desjeux 1998, Funasa/MS 2000).

The various side-effects and the resistance to available drugs, in addition to the increase in new cases, have led to the urgent need for new therapeutic agents to treat these diseases. We have evaluated the trypanocidal and

+Corresponding author. E-mail: darvenne@unb.br Received 12 July 2005

Accepted 29 September 2005 leishmanicidal activity in vitro of crude Brazilian Cerrado plant extracts, the country's second most important biome. Plants were selected among traditional healers for their use against cutaneous and infectious diseases, such as ulcers, diarrhea, fever, and malaria. In Brazil, populations in rural areas rely on traditional medicine for the treatment of many infectious diseases.

\section{MATERIALS AND METHODS}

Plant material and extract preparation - The plants were collected in Brasília, the Federal District of Brazil, in $2002 / 2003$. Botanical identification was performed by Professor José Elias de Paula of the Vegetal Anatomy Laboratory, Institute of Biology, University of Brasília (UnB). The voucher botanic specimens are deposited at the Herbarium (UB) of that institution (Table I).

The air-dried and powdered parts of the different plants (400 g) were submitted first to exhaustive extractions with hexane $(4 \times 21)$, and successively with ethanol $(4 \times 21)$ through a maceration process. The crude extracts were obtained after the evaporation of the solvents under reduced pressure at $40^{\circ} \mathrm{C}$, which is a technique routinely used at the Pharmacognosy Laboratory of the University of Brasília Health Science School.

Biological assays - Assays were performed by the Department of Parasitology of the Faculty of Pharmacy of Châtenay-Malabry (Paris XI, France), and the Muséum d'Histoire Naturelle de Paris, France.

Trypanocidal assay - In vitro assays against the intracellular amastigote form were performed as described 
(Grellier et al. 2001) using a $\beta$-galactosidase-expressing parasite (Tulahuen LacZ clone 4) kindly provided by W Van Voorhis (University of Washington, Seattle, Washington, US). Briefly, murine muscle L6 cells were seeded in a 96-well plate at $5 \times 10^{3}$ cells/well. After $24 \mathrm{~h}, 10^{5}$ trypomastigote forms obtained from infected cultures of L6 cells were added to each well for $6 \mathrm{~h}$. Cells were washed twice to remove extracellular trypomastigotes, and incubated with 2-fold dilutions of the drug, at $37^{\circ} \mathrm{C}$, under a $5 \% \mathrm{CO}_{2}$ atmosphere for 5 days in RPMI 1640 medium supplemented by $25 \mathrm{mM}$ HEPES, pH 7.35 and $10 \%$ fetal calf serum (FCS). In all these experiments, untreated parasite cultures were used as negative controls. Growth inhibition was quantified using the chromogenic substrate red $\beta$-D-galactopyranoside according to Buckner et al. 1999. $\mathrm{IC}_{50}$ values were calculated from dose-response curves obtained from several independent experiments. Benznidazole was used as reference drug.

Cytotoxicity test on mammalian cells - L-6 cells was seeded into 96-well microplates at 5000 cells/well in 100 $\mu 1$. After $24 \mathrm{~h}$, the cells were washed and maintained with different concentrations of extracts for 5 days, at $37^{\circ} \mathrm{C}$ under a $5 \% \mathrm{CO}_{2}$ atmosphere. Cytotoxicity was determined using the colorimetric tetrazolium-dye (MTT) assay following the manufacturer's recommendations (Cell proliferation kit I, Boehringer Mannheim S.A., Meylan, France). The $\mathrm{IC}_{50}$ values were obtained from the drug concentration-response curve. The results were expressed as the mean \pm the standard deviations determined from three independent experiments.

Antileishmanicidal assay - L. donovani (MHOM/ET/ L82/LV9) promastigotes were kindly provided by Pr SL Croft, from the WHO collection at the London School of Hygiene and Tropical Medicine. Assays were performed as previously described by M'Bongo et al. (1997) and Okpekon et al. (2004). Briefly, promastigotes were grown at $27^{\circ} \mathrm{C}$ in HEPES ( $25 \mathrm{mM}$ ) buffered RPMI 1640 medium containing $10 \% \mathrm{FCS}$ and $50 \mu \mathrm{g} / \mathrm{ml}$ gentamycin. Assays were performed in 96-well microtitre plates. Drugs were serially diluted in culture medium ( $100 \mu \mathrm{l} /$ well); $100 \mu \mathrm{l}$ of parasites from a logarithmic phase culture $\left(1.75 \times 10^{6}\right.$ promastigotes $/ \mathrm{ml}$ ) were then added to each well and plates were maintained at $27^{\circ} \mathrm{C}$ under a $5 \% \mathrm{CO}_{2}$ atmosphere. Biological tests were performed four times, and each tested concentration in duplicate. The viability of parasites was evaluated by the MTT colorimetric method. The antileishmanial activity was expressed as the $\mathrm{IC}_{50}$ after a $72 \mathrm{~h}$ incubation period. The initial concentration for screening was $15 \mu \mathrm{g} / \mathrm{ml}$. Pentamidine, amphotericin B and miltefosine were used as reference drugs.

\section{RESULTS AND DISCUSSION}

In our search for natural products with leishmanidal and trypanocidal activity, we assayed hexanic and ethanolic crude extracts of native plants from the Brazilian Cerrado. Table I lists the thirteen plants selected, their botanical families and the voucher number. Thirty one extracts were prepared from different parts of the plants.

Nineteen crude extracts showed an inhibition greater than $50 \%$ at a concentration of $15 \mu \mathrm{g} / \mathrm{ml}$ against promas- tigote forms of $L$. donovani and were further investigated to determine their $\mathrm{IC}_{50}$ values (Table II). The strongest activity, with $\mathrm{IC}_{50}$ values ranging from 0.1 to $4.9 \mu \mathrm{g} / \mathrm{ml}$, was found for Casearia sylvestris var. lingua: the hexanic extracts of leaves, stem wood and bark, and root bark, and the ethanolic extract of root bark and fruits, as well as the ethanolic extracts of Annona crassiflora root bark. The results also indicated $\mathrm{IC}_{50}$ values ranging from 5 to $10 \mu \mathrm{g} /$ $\mathrm{ml}$ for the hexanic extracts of Cupania vernalis leaves, Guarea kunthiana root and for the ethanolic extracts of A. crassiflora stem wood and root wood, Himatanthus obovatus root wood, and Serjania lethalis root bark.

For $T$. cruzi, among the plants tested, the most effective extracts were the hexanic extract of $C$. sylvestris var. lingua, which showed $\mathrm{IC}_{50}$ values ranging from 0.3 to 3.4 $\mu \mathrm{g} / \mathrm{ml}$ : leaves, stem wood and bark, and root wood and bark. The results also indicated $\mathrm{IC}_{50}$ values ranging from 5 to $10 \mu \mathrm{g} / \mathrm{ml}$ for the hexanic extract of Duguetia furfuracea bark root, as well as the ethanolic extracts of $C$. sylvestris var. lingua root bark, and A. crassiflora root wood and bark.

A. crassiflora is traditionally used against Chagas disease (Queiroz et al. 1996), as well as snake bites (seeds) (Correia 1984). The total alkaloids of A. crassiflora were shown to be active against $L$. chagasi $\left(\mathrm{IC}_{50}\right.$ value $=24.9$ $\mu \mathrm{g} / \mathrm{ml}$ ), and trypomastigote forms of T. cruzi, killing $100 \%$ of the parasites at $100 \mu \mathrm{g} / \mathrm{ml}$ (Tempone et al. 2005). It must be noted that other studies have reported the leishmanidal and trypanocidal activities of extracts and isolated compounds from other species of this genus (Sahpaz et al. 1994, Jaramillo et al. 2000, Tempone et al. 2005). Various acetogenins were isolated from the genera Annona (Gleye et al. 2001, Wang et al. 2002, Bermejo et al. 2005); acetogenins are known for their antiprotozoal activity, including against $L$. donovani (Raynaud-Le Grandic et al. 2004), which could explain the antiparasite activity observed for A. crassiflora.

C. sylvestris var. lingua demonstrated to be more potent than the other species tested. In both assays, almost all the plant organs showed antiprotozoal activity, indicating that there might be similar types of secondary metabolites. This variety was also active against epimastigote forms of T. cruzi (Espindola et al. 2004). Casearia ssp. showed activity in other biological systems, as the downmodulation of nitric production in murine macrophages (Napolitano et al. 2005) or in neutralizing proteases from venoms (Borges et al. 2001), which are probably linked to the presence of diterpenes (de Carvalho et al. 1998, Oberlies et al. 2002).

Two different species of Guarea (G. guidonia, G. polymera) were evaluated against Plasmodium falciparum, T. cruzi, and Leishmania sp. showing good antiprotozoal activity in vitro (Weniger et al. 2001).

Preliminary cytotoxicity assays upon the mammalian L6 cells showed that the hexanic extract of A. crassiflora root bark is weakly cytotoxic $\left(\mathrm{IC}_{50}\right.$ value $=45.2 \pm 2.2 \mu \mathrm{g}$ / $\mathrm{ml}$ ), as well as the hexanic extract of $D$. furfuracea root bark $\left(\mathrm{IC}_{50}\right.$ value $\left.=62.6 \pm 2.2 \mu \mathrm{g} / \mathrm{ml}\right)$. In contrast $C$. sylvestris var. lingua showed marked cytotoxicity effect $\left(\mathrm{IC}_{50}\right.$ value $=1.7 \pm 0.8 \mu \mathrm{g} / \mathrm{ml})$. 
TABLE I

Plants studied and their traditional use

\begin{tabular}{|c|c|c|c|}
\hline Plant species (family) & Voucher No. & Vernacular name & Traditional use in medicine \\
\hline $\begin{array}{l}\text { Annona crassiflora Mart. } \\
\text { (Annonaceae) }\end{array}$ & (UB) 3700 & marôlo, araticum-do-Cerrado & fever, Chagas disease \\
\hline $\begin{array}{l}\text { Cardiopetalum calophyllum Schl. } \\
\text { (Annonaceae) }\end{array}$ & (UB) 3703 & imbirinha, imbiribeira, imbira-amarela & fever \\
\hline $\begin{array}{l}\text { Duguetia furfuracea (A. St. Hil.) } \\
\text { Benth \& Hook(Annonaceae) }\end{array}$ & (UB) 3679 & $\begin{array}{l}\text { araticum-seco, araticunzinho, } \\
\text { pinha-de-guará }\end{array}$ & dysenteric syndrome fever \\
\hline $\begin{array}{l}\text { Xylopia aromatica (Lam.) } \\
\text { Mart.(Annonaceae) }\end{array}$ & (UB) 3699 & $\begin{array}{l}\text { pimenta-de macaco, } \\
\text { pimenta-do-campo }\end{array}$ & condiment, carminative \\
\hline $\begin{array}{l}\text { Xylopia emarginata Mart. } \\
\text { (Annonaceae) }\end{array}$ & (UB) 3690 & $\begin{array}{l}\text { pindaíba-reta, pindaíba d'água, } \\
\text { pindaíba-do-brejo }\end{array}$ & antibacterial \\
\hline $\begin{array}{l}\text { Aspidosperma macrocarpon } \\
\text { Woodson(Apocynaceae) }\end{array}$ & (UB) 3692 & $\begin{array}{l}\text { guatambu-do-cerrado, pau-pereira, } \\
\text { peroba-do-campo }\end{array}$ & fever, malaria \\
\hline $\begin{array}{l}\text { Himatanthus obovatus (Müll. Arg.) } \\
\text { Woodson (Apocynaceae) }\end{array}$ & (UB) 3678 & tiborna, pau-de-leite, janaguba & cancer, herpes, verminosis \\
\hline $\begin{array}{l}\text { Casearia sylvestris Sw.var. lingua } \\
\text { (Camb.) Eichl.(Flacourtiaceae) }\end{array}$ & (UB) 3693 & $\begin{array}{l}\text { erva-de-lagarto, } \\
\text { cafezeiro-do-mato }\end{array}$ & $\begin{array}{l}\text { analgesic (pain-reliever), } \\
\text { anti-inflammatory, } \\
\text { antibacterial, anticancerous }\end{array}$ \\
\hline $\begin{array}{l}\text { Guarea kunthiana A. Juss. } \\
\text { (Meliaceae) }\end{array}$ & (UB) 3710 & jataúba da Guiana & antiinflammatory \\
\hline $\begin{array}{l}\text { Cupania vernalis Camb. } \\
\text { (Sapindaceae) }\end{array}$ & (UB) 3695 & camboatã-vermelho, olho-de-cotia & fever, tonic, inflammation \\
\hline $\begin{array}{l}\text { Matayba guianensis Aubl. } \\
\text { (Sapindaceae) }\end{array}$ & (UB) 3697 & camboatá, assa-leitão & comestible fruit \\
\hline $\begin{array}{l}\text { Serjania lethalis A. St. Hil. } \\
\text { (Sapindaceae) }\end{array}$ & (UB) 3716 & timbó & ichtyotoxic \\
\hline $\begin{array}{l}\text { Pouteria gardneri } \\
\text { (Mart. \& Miq.)(Sapindaceae) }\end{array}$ & (UB) 3672 & $\begin{array}{l}\text { leiteiro-da-folha-miúda, sapotinha, } \\
\text { aguaí-guaçu }\end{array}$ & $\begin{array}{l}\text { construction, } \\
\text { comestible fruit }\end{array}$ \\
\hline
\end{tabular}

C. sylvestris var. lingua and A. crassiflora extracts are as efficient as the reference drugs used against both parasites. As these plants are widely used in traditional medicine in Brazilian Cerrado against cutaneous and infectious diseases, these results prompted us to perform bioassay guided fractionations, and further experiments with T. cruzi and Leishmania animal models to evaluate their efficacy against both parasites.

\section{REFERENCES}

Bermejo A, Figadere B, Zafra-Polo MC, Barrachina I, Estornell E, Cortes D 2005 Acetogenins from Annonaceae: recent progress in isolation, synthesis and mechanisms of action. Nat Prod Rep 22: 269-303.

Borges MH, Soares AM, Rodrigues VM, Oliveira F, Fransheschi AM, Rucavado A, Giglio JR, Homsi-Brandeburgo MI 2001. Neutralization of proteases from Bothrops snake venoms by the aqueous extract from Casearia sylvestris (Flacourtiaceae). Toxicon 39: 1863-1869.

Buckner FS, Wilson AJ, Van Voorhis WC 1999. Detection of live Trypanosoma cruzi in tissues of infected mice by using histochemical stain for beta-galactosidase. Infect Immun 67: 403-409.
Correia MP 1984. Dicionário das Plantas Úteis do Brasil e das Exóticas Cultivadas, Imprensa, Rio de Janeiro.

de Carvalho PR, Furlan M, Young MC, Kingston DG, Bolzani VS 1998. Acetylated DNA-damaging clerodane diterpenes from Casearia sylvestris. Phytochemistry 49: 1659-1662.

Desjeux P 1998. UNAIDS. Leishmania and HIV in gridlock. WHO and UN programme on HIV/AIDS, WHO/CTD/ LEISH/98.9, Geneva.

Espindola LS, Vasconcelos Junior JR, de Mesquita ML, Marquie P, de Paula JE, Mambu L, Santana JM 2004. Trypanocidal activity of a new diterpene from Casearia sylvestris var. lingua. Planta Med 70: 1093-1095.

Funasa-Fundação Nacional de Saúde-Ministério da Saúde 2000. Manual de Controle da Leishmaniose Tegumentar Americana, Brasília-DF, 62 pp.

Gleye C, Akendengue B, Laurens A, Hocquemiller R 2001. Coronin from roots of Annona muricata, a putative intermediate in acetogenin biosynthesis (1). Planta Med 67: 570572.

Grellier P, Vendeville S, Joyeau R, Drobecq H, Frappier F, Teixeira ARL, Schrével J, Davioud-Charvet E, Sergheraert C, Santana J 2001. Trypanosoma cruzi prolyl oligopeptidase 
TABLE II

In vitro activities of extracts of Brazilian Cerrado plants against amastigote forms of Trypanosoma cruzi and promastigote forms of Leishmania donovani

\begin{tabular}{|c|c|c|c|}
\hline Species & Parts and solvents & $\begin{array}{l}\text { T. cruzi amastigotes } \\
\operatorname{IC}_{50}(\mu \mathrm{g} / \mathrm{ml})\end{array}$ & $\begin{array}{l}\text { L. donovani promastigotes } \\
\operatorname{IC}_{50}(\mu \mathrm{g} / \mathrm{ml})\end{array}$ \\
\hline Annona crassiflora & $\begin{array}{l}\text { SB (e) } \\
\text { SW (e) } \\
\text { SW (h) } \\
\text { RB (e) } \\
\text { RB (h) } \\
\text { RW (e) }\end{array}$ & $\begin{array}{c}14.9 \pm 2.3 \\
20.5 \pm 1.1 \\
45.9 \pm 3.1 \\
5.9 \pm 1.3 \\
18.6 \pm 6.8 \\
9.9 \pm 0.5\end{array}$ & $\begin{array}{c}12.4 \pm 0.3 \\
8.3 \pm 0.8 \\
3.7 \pm 0.3 \\
8.7 \pm 0.6\end{array}$ \\
\hline Cardiopetalum calophyllum & $\mathrm{SB}(\mathrm{h})$ & $60.4 \pm 2.6$ & \\
\hline Duguetia furfuracea & $\begin{array}{l}\text { S (h) } \\
\text { RB (e) } \\
\text { RB (h) } \\
\text { RW (e) }\end{array}$ & $\begin{array}{c}50.0 \pm 1.6 \\
30.4 \pm 1.3 \\
6.6 \pm 0.6 \\
25.6 \pm 1.5\end{array}$ & \\
\hline $\begin{array}{l}\text { Xylopia aromatica } \\
\text { Xylopia emarginata }\end{array}$ & $\begin{array}{l}\text { RW (h) } \\
\text { RB (h) } \\
\text { L (h) }\end{array}$ & $\begin{array}{l}21.6 \pm 6.0 \\
23.5 \pm 4.7 \\
57.6 \pm 2.4\end{array}$ & \\
\hline Aspidosperma macrocarpon & $\mathrm{L}(\mathrm{h})$ & $59.2 \pm 1.2$ & \\
\hline Himatanthus obovatus & RW (e) & $15.7 \pm 0.5$ & $7.5 \pm 0.9$ \\
\hline Casearia sylvestris var. lingua & $\begin{array}{l}\text { L (h) } \\
\text { SB (e) } \\
\text { SB (h) } \\
\text { SW (h) } \\
\text { RB (e) } \\
\text { RB (h) } \\
\text { RW (e) } \\
\text { RW (h) } \\
\text { F (h) } \\
\text { F (e) }\end{array}$ & $\begin{array}{c}3.40 \pm 0.35 \\
0.44 \pm 0.02 \\
0.44 \pm 0.05 \\
5.6 \pm 0.4 \\
0.3 \pm 0.04 \\
0.86 \pm 0.05\end{array}$ & $\begin{array}{c}3.7 \pm 0.3 \\
11.4 \pm 0.2 \\
0.2 \pm 0.0 \\
0.3 \pm 0.0 \\
0.1 \pm 0.0 \\
1.0 \pm 0.1 \\
5.0 \pm 0.1 \\
11.4 \pm 0.2 \\
9.5 \pm 0.6 \\
4.9 \pm 0.2\end{array}$ \\
\hline Guarea kunthiana & $\mathrm{R}(\mathrm{h})$ & & $7.9 \pm 1.3$ \\
\hline Cupania vernalis & $\mathrm{L}(\mathrm{h})$ & & $7.1 \pm 0.6$ \\
\hline Matayba guianensis & SB (h) & $14.8 \pm 0.5$ & $10.7 \pm 0.7$ \\
\hline Serjania lethalis & $\mathrm{RB}(\mathrm{e})$ & & $5.2 \pm 0.3$ \\
\hline Pouteria gardneri & RW (h) & $45.5 \pm 5.9$ & \\
\hline \multicolumn{4}{|l|}{ Reference drugs } \\
\hline Benznidazole & & $1.0 \pm 0.1$ & \\
\hline Amphotericin B & & & $0.8 \pm 0.1$ \\
\hline Pentamidine & & & $3.1 \pm 0.6$ \\
\hline Miltefosine & & & $3.1 \pm 0.1$ \\
\hline
\end{tabular}

L: leaves; R: roots; F: fruits; S: stem; SB: stem bark; SW: stem wood; RB: root bark; RW: root wood; e: ethanol; h: hexane

Tc80 is involved in non-phagocytic mammalian cell in by trypomastigotes. J Biol Chem 276: 47078-86.

Jaramillo MC, Arango GJ, Gonzalez MC, Robledo SM, Velez ID 2000. Cytotoxicity and antileishmanial activity of Annona muricata pericarp. Fitoter 71: 183-186.

M'Bongo N, Loiseau P, Lawrence F, Bories C, Craciunescu DG, Robert-Gero M 1997. In vitro sensivity of Leishmania donovani to organometallic derivatives of pentamidine. Parasitol Res 83: 515-517.
Napolitano DR, Mineo JR, Souza MA, Paula JE, Espindola LS, Espindola FS 2005. Down-modulation of nitric oxide production in murine macrophages treated with crude plant extracts from the Brazilian Cerrado. J Ethnopharmacol 99: $37-41$.

Oberlies NH, Burgess JP, Navarro HA, Pinos RE, Fairchild CR, Peterson RW, Soejarto DD, Farnsworth NR, Kinghorn AD, Wani MC, Wall ME 2002. Novel bioactive clerodane diterpenoids from the leaves and twigs of Casearia sylvestris. J Nat Prod 65: 95-99. 
Okpekon T, Yolou S, Gleye C, Roblot F, Loiseau P, Bories C, Grellier P, Frappier F, Laurens A, Hocquemiller R 2004. Antiparasitic activities of medicinal plants used in Ivory Coast. J Ethnopharmacol 90: 91-97.

Paris C, Loiseau PM, Bories C, Breard J 2004. Miltefosine induces apoptosis-like death in Leishmania donovani promastigotes. Antimicrob. Agents Chemother 48: 852-859.

Queiroz EF, Roblot F, Cavé A, Paulo MQ, Fournet A 1996. Pessoine and spinosine, two catecholic berbines from Annona spinescens. J Nat Prod 59: 438-440.

Raynaud-Le Grandic S, Fourneau C, Laurens A, Bories C, Hocquemiller R, Loiseau PM 2004. In vitro antileishmanial activity of acetogenins from Annonaceae. Biomed Pharmacother 58: 388-392.

Sahpaz S, Bories C, Loiseau PM, Cortes D, Hocquemiller R, Laurens A, Cave A 1994. Cytotoxic and antiparasitic activity from Annona senegalensis seeds. Planta Med 60: 538540.

Tempone AG, Treiger Borborema SE, de Andrade Jr. HF, de
Amorim Gualda NC, Yogi A, Salerno Carvalho C, Bachiega D, Lupo FN, Bonotto SV, Fischer DCH 2005. Antiprotozoal activity of Brazilian plant extracts from isoquinoline alkaloid-producing families. Phytomedicine 12: 382-390.

Urbina JA 1999. Chemotherapy of Chagas disease: the how and the why. J Mol Med 77: 332-328.

Urbina JA, Docampo R 2003. Specific chemotherapy of Chagas disease: controversies and advances. Trends Parasitol 11: 495-501.

Wang LQ, Min BS, Li Y, Nakamura N, Qin GW, Li CJ, Hattori M 2002. Annonaceous acetogenins from the leaves of Annona montana. Bioorg Med Chem 10: 561-565.

Weniger B, Robledo S, Arango GJ, Deharo E, Aragon R, Munoz V, Callapa J, Lobstein A, Anton R 2001. Antiprotozoal activities of Colombian plants. J Ethnopharmacol 78: 193200.

WHO-World Health Organization 2002. Control of Chagas Disease, Tech Rep Ser 905, p. 1-109. 